\title{
nature
}

\section{Nuclear power stations for sale?}

\section{The newly re-elected British government says that it plans to denationalize its electricity utilities, but}

that it has not yet decided how. Here, gratuititously, is some advice.

THE re-election last Thursday of Mrs Margaret Thatcher's British government is not, in itself, a surprise, although the size of its majority seems to have startled even those who will enjoy it for the next five years. On the face of things, the development will further disappoint those in Britain who have been wringing their hands over the condition of the British research enterprise for the past several years, Nature among them. Yet that could be too gloomy a view. The simple arithmetical argument that the government will be almost as able as in the previous parliament to subdue opposition with its voting strength is only half the truth. The other is that its quite remarkable electoral achievement may have two psychological consequences - that of making it at once more daring, or more radical, and that of giving it a confidence belied by its defensive impulsiveness of the past few years which, among other things, may allow it to listen to its critics. Since there is no prospect of a change in the political scene for close on five years (if then), that at least is how the critics might best arrive at an accommodation with events.

The obvious agenda on which the new government appears ready to embark has education significantly near the top of the list, and for practical reasons. The plan that there should be a nationally uniform curriculum in secondary schools requires that the government should have power to tell local education authorities, hitherto paramount in this respect, what their schools should teach. Plans centrally to support the polytechnics require legislation allowing them to be removed from the control of the same authorities. And if the University Grants Committee is to be replaced by a University Funding Council, with or without power to make contracts with universities, there will have to be legislation to that effect. Whether the new government will persist with its old ambitions to abolish academic tenure remains to be seen, but there is no doubt that the parliamentary row about the education bill will centre on the proposals, sprung on a startled British electorate towards the end of the election, that any school might opt out of local education authority control if its governors or its students' parents so wished. Behind the dust-storm these proposals are certain to raise, there should be ample opportunity for safeguarding against some of the proposals on higher education to which the previous government nervously attached itself.

The starting-point for reasoned argument should be an understanding of why the British government appears to be moved by discontent with the research enterprise for which it pays the bill (see Nature 327, 448; 1987). It believes that universities are not properly accountable for the subsidies they enjoy and that, in their pursuit of research, they have been waywardly neglectful of the needs of industry. (Separately, the British government also inclines to the view that its research councils are managed indecisively.) But the parliamentary argument will be fought over the detailed proposals which, in the government's opinion, have been devised to correct these evils. With a majority of more than a hundred in the House of Commons, there is no reason why the government should give way on the details of its policy unless it is persuaded that its objectives might be better attained in some other way.

What other courses of action might there be? Anomalously, universities would be more acutely aware of their financial responsibility for spending public money wisely if they were more, and not less, free to determine their own affairs. The weakness in present arrangements is that universities know that there are strong political reasons why they will not be allowed to go out of business, even if they should grossly mismanage their affairs. The proposed system of financing by means of contracts with the funding council, while adding an element of arbitrariness to university planning, will further dilute academics' responsibility for their institutions' survival. Why not push the system in the opposite direction by means of arrangements to ensure that their survival as institutions is in their own hands? One simple way of doing this would be to increase the money value of students' tuition fees, at present only nominal and paid by the central government direct to universities through the intermediary of local education authorities. A government whose radicalism centres around the belief that the market works wonders must surely be open to persuasion in that direction, but would universities take the risk?

\section{Is health affordable?}

All governments are worried about rising health costs; are health economists a sufficient answer?

For most of the past 40 years, many US physicians and some US politicians have described the British National Health Service as "socialized medicine", partly because the services of a large proportion of British physicians are now formally contracted by the state. So what is to be made of this decade's tendency in the United States for physicians to be salaried employees of healthcare corporations whose revenues are derived from the now bewildering variety of health plans to which individuals belong, to which their employers often contribute and which are also subsidized by the federal government either directly or through tax exemptions (reckoned to cost more than $\$ 50,000$ million this year)? And what is to be said of the tendency of the US Congress to limit the fees the government's own health care schemes, Medicare and Medicaid, will pay physicians and hospitals for particular services? Is that creeping socialized medicine, or otherwise a sign of how some future British government may shed the administrative burden of running Britain's hospitals and other health-care services?

The changing machinery of health care in the market economy of the United States is succinctly described by Alain Enthoven, a consultant to Health and Social Services Secretary Joseph Califano during the Carter administration, in a symposium published this week (Health economics - prospects for the future, G. Teeling Smith (ed.); Croom Helm for the Office of Health Economics). the overt agenda is the undoubted importance of economics in understanding the benefits of health care and in controlling the costs thereof, but the book is also a valuable summary of how different countries handle the costs of health care. The arresting statistic is that spending on health care in the United States increased from $5 \cdot 3$ per cent of Gross National Product in 1960 to 10.7 per cent in 1983, and continues 